\title{
TIPOLOGI EKSPANSI MUSEUM
}

\author{
Arja Wendra Nityasa ${ }^{1)}$, Sutarki Sutisna ${ }^{2)}$
}

1)Program Studi S1 Arsitektur, Fakultas Teknik, Universitas Tarumanagara, arjan.ta@stu.untar.ac.id

2) Program Studi S1 Arsitektur, Fakultas Teknik, Universitas Tarumanagara, sutarkis@gmail.com

\begin{abstract}
Abstrak
Sebuah bangunan karya arsitektur diciptakan untuk memiliki sebuah fungsi utama sehingga dapat disebut sebagai sekolah, kantor dan khususnya museum. Namun, akibat perkembangan zaman, pengaruh kemajuan teknologi dan perubahan gaya hidup masyarakat dapat mengurangi antusiasme terhadap bangunan tersebut sehingga perlu adanya kebutuhan ruang tambahan yang sesuai dengan kebutuhan masyarkat, dimasukan ke dalam fungsi-fungsi utama tersebut. Namun, untuk membuat sesuatu yang baru perlu memperhatikan konteks terhadap apa yang sudah ada sebelumnya. Menurut Prof.Bill Raun akademisi Oklahoma State University menyatakan bahwa kontekstual menekankan bahwa sebuah bangunan harus mempunyai kaitan dengan lingkungan (bangunan yang berada di sekitarnya). Keterkaitan tersebut dapat dibentuk melalui proses menghidupkan kembali nafas spesifik yang ada dalam lingkungan (bangunan lama) ke dalam bangunan yang baru sesudahnya. Jurnal Tipologi Expansi Museum ingin menunjukan sebagian kecil proses desain dan kaidah yang perlu diperhatikan saat merancang perluasan museum yang mengakomodasi fungsi baru yang sesuai dengan tuntutan masyarakat dan perkembangan zaman atau menampung benda pamer yang semakin bertambah. Proses analisis dilakukan melalui pengamatan melalui pengambilan sampel sepuluh expansi museum dari seluruh dunia yang dianalisis dengan variabel yang sama untuk mencari pola-pola tertentu dan mencari hubungan antara bangunan museum yang baru dengan yang lama.
\end{abstract}

Kata kunci: Ekspansi; Museum; Tipologi

\begin{abstract}
A building of architectural works was created to have a main function so that it could be called a school, office and especially a museum. However, due to the development of the times, the influence of technological advances and changes in people's lifestyles can reduce enthusiasm for the building so that the need for additional space in accordance with the needs of the community, is included in the main functions. However, to make something new it is necessary to pay attention to the context of what was already there. According to Prof. Bill Raun Oklahoma State University academics stated that contextual emphasizes that a building must have a relationship with the environment (buildings that are around it). These linkages can be formed through the process of reviving the specific breaths that exist in the environment (old buildings) into new buildings afterwards The Museum's Extension Typology Journal wants to show a small part of the design process and rules that need to be considered when designing an expansion of the museum that accommodates new functions that are in accordance with the demands of the community and the times or accommodates the increasing number of showing objects. The analysis process was carried out through observation through sampling ten museum extensions from around the world that were analyzed with the same variables to look for certain patterns and look for relationships between new museum buildings and the old ones.
\end{abstract}

Keywords: Expansion; Museum; Typology

\section{PENDAHULUAN}

Tujuan dari penulisan jurnal ini adalah untuk menunjukan metode perancangan bangunan ekspansi museum melalui titik, garis dan sumbu axis yang dicari melalui metode dengan mengacu pada prinsip-prinsip perancangan yang dituturkan oleh D.K. 
Ching. Dalam merancang sesuatu yang baru perlu melihat bagaimana yang lama, tentang kekurangan maupun kelebihan. Untuk melakukan metode ini pertama-tama perlu melihat konteks dari site yang akan diolah, khususnya garis sumbu axis dan hirarki bangunan. Tujuannya adalah sebagai investigasi bagaimana bangunan lama terbentuk sehingga bangunan baru dapat mengikuti pola dan karakter yang telah ada.

\section{KAJIAN LITERATUR}

\section{Variabel Analisis}

Dalam analisis tipologi ekpansi museum, perlunya menelaah tentang bagaimana posisi bangunan baru terhadap bangunan lama atau dengan kata lain bagaimana bangunan ekspansi tersebut dirancang. Sehingga untuk memulai investigasi tentang bentuk massa, konfigurasi dan sirkulasi, perlu adanya langkah mundur untuk mengetahui ide desain sebuah desain ekspansi museum. Dalam analisis ini digunakan teori oleh Francis D.K. Ching sebagai berikut :

a. Prinsip Penyusunan Komposisi

Menurut D.K. Ching, Tatanan tidak hanya merujuk pada sisi geometris saja, tetapi merujuk kepada hal lainnya untuk menemukan sebuah harmonisasi di dalam bangunan seperti hirarki yang terdapat dalam pemrograman, perancangan dan pembuatan bangunan yang dapat disebut sebagai prinsip-prinsip penyusunan.

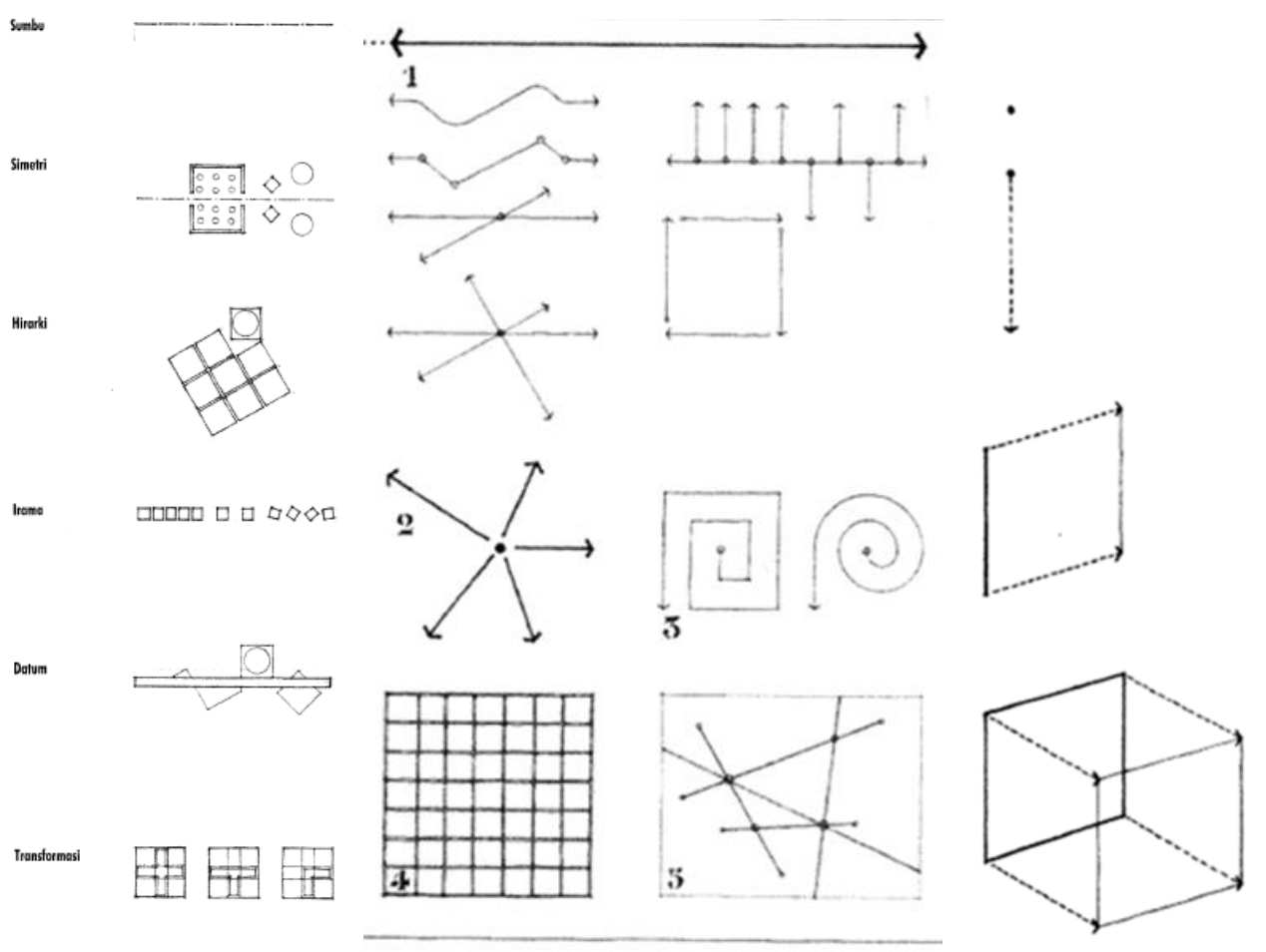

Gambar 1. Prinsip Penyusunan Komposisi Sumber : Ching, 2008

\section{b. Elemen-Elemen Utama}

Dalam perbendaharaan desain arsitektur, terdapat elemen-elemen konseptual yaitu titik, garis, bidang dan volume. Ketika elemen-elemen tersebut diolah dapat menjadi bentuk dengan karakteristik unsur, bentuk, ukuran, warna dan tekstur. 
c. Bentuk

Menurut Psikolog Gestalt, pikiran manusia akan menyederhanakan lingkungan visual agar dapat memahaminya dengan menyederhanakan bentuk tersebut. Menurut D.K. Ching, bentuk-bentuk dasar utama adalah lingkaran, segitiga dan bujursangkar.

d. Konfigurasi Jalur

Sifat konfigurasi sebuah jalur mempengaruhi dan juga dipengaruhi oleh pola organisasi ruang-ruang yang dihubungkannya. Konfigurasi jalur dapat memperkuatsebuah organisasi spasialdengan carai menyejajarkan pola. Memetakan konfigurasi jalur-jalur di dalam sebuah bangunan, makan oritenasi serta pengertian tata letak dalam bangunan itu dapat menjadi jelas. Jenis-jenis konfigurasi jalur yaitu :

1. Linear, yaitu jalur yang lurus. Jalur ini dapat berbentuk kurva atau terpotongpotong.

2. Radial, yaitu sejumlah jalur linear yang berakhir pada sebuah titik pusat yang sama.

3. Spiral, yaitu sebuah jalur tunggal yang berawal dari satu titik pusat yang bergerak melingkar menjauhi titik pusat.

4. Grid, yaitu terdiri dari dua buah jalur yang sejajar dan saling berpotongan membentuk bujursangkar atau persegi panjang.

5. Jaringan, merupakan jalur-jalur yang menghubungkan titik-titik yang terbentuk di dalam ruang.

6. Komposit, yaitu kombinasi dari dua buah atau lebih konfigurasi sirkulasi.

\section{METODE}

Untuk memahami tipologi expansi museum, metode yang digunakan adalah kualitatif, dimulai dengan mengambil 10 sampel expansi museum dari seluruh dunia. Sampel diambil dari sepuluh extension-museum dari seluruh dunia, yaitu Landesmuseum(Swiss), The Broad(USA). Ontario Royal Museum(Kanada), Denver Art Museum(USA), Stedelijk Museum(Belanda),M 9 Distric (Italia), Quebec Art Museum(Kanada) dan Museum De Fundatie (Belanda). Kemudian, sampel-sampel tersebut dianalisis berdasasrkan teori yang ada di Kajian Teoritis. Dimulai dari melihat bentukan dasar dari massa bangunan, organisasi massa, hirarki, geometri dasar, simetris dan keseimbangan. Dari variable tersebut didapatkan beberapa hasil yang menjadi dasar untuk analisis proyek. Bentuk dasar, massa bangunan, geometri dasar, simetris dan keseimbangan dapat menghasilkan sebuah metode analisis dengan melihaat bentuk dasar dan axis yang terbentuk, baik melalui site terhadap bagian kota yang menarik, bentuk dasar bangunan, hirarki bentuk dan bentuk dasar bangunan baru dan lama. Kemudia bentuk dasar geometri tersebut memiliki masing-masing axis-axis yang dapat dilihat menjadi proses desain sebuah bangunan. Hasil analisis kedua yang dapat digunakan untuk dasar mendesain adalah pergerakan atau alur pergerakan manusia dan sirkulasi di dalam museum. Hasil analisis ketiga yang dapat dijadikan rujukan desain adalah massa bangunan. Dapat diketahui bahwa antara bangunan lama dengan bangunan baru harus serasi, maksudnya adalah secara bentuk dan besaran harus sebanding, bangunan baru tidak boleh melebihi bangunan lamanya.

\section{DISKUSI DAN HASIL}

Terdapat sebelas poin dari sepuluh museum yaitu Landesmuseum(Swiss), The Broad(USA). Ontario Royal Museum(Kanada), Denver Art Museum(USA), Stedelijk Museum(Belanda),M 9 Distric (Italia), Quebec Art Museum(Kanada) dan Museum De Fundatie (Belanda). analisis hubungan antara museum dengan bangunan ekspansinya. Yang pertama adalah dengan 
melihat konteks urban atau sekitarnya. Ekspansi museum yang merupakan bangunan baru harus menjadi satu kesatuan dengan bangunan lama.

Jika dianalisis dari simetri dan keseimbangan bangunan dan dibandingkan dengan organisasi massa,diketahui ternyatai bangunan yang baru mengikuti axis dan sumbu simetri bangunan lama, meskipun bangunan ekspansi bisa membentuk kembali axis baru namun harus mengkuti pola eksisting. Dari besaran massing anatara bangunan eksisting dengan bangunan ekspansi, diketahui bahwa bangunan ekspansi memiliki besaran yang sepadan dengan bangunan eksisting atau dapat lebih besar namun dengan Batasan tertentu.Kemudia, dilihat dari sirkulasi, bangunan ekspansi tetap mengikuti sirkulasi bangunan yang lama, dengan catatan jika bangunan tersebut terpisah dari bangunan eksisting, dapat membentuk sirkulasi yang baru, seperti kasus Museum M9. Meskipun membentuk sirkulasi yang baru tetap memprioritaskan bangunan eksisting sebagai jalur sirkulasi utama.

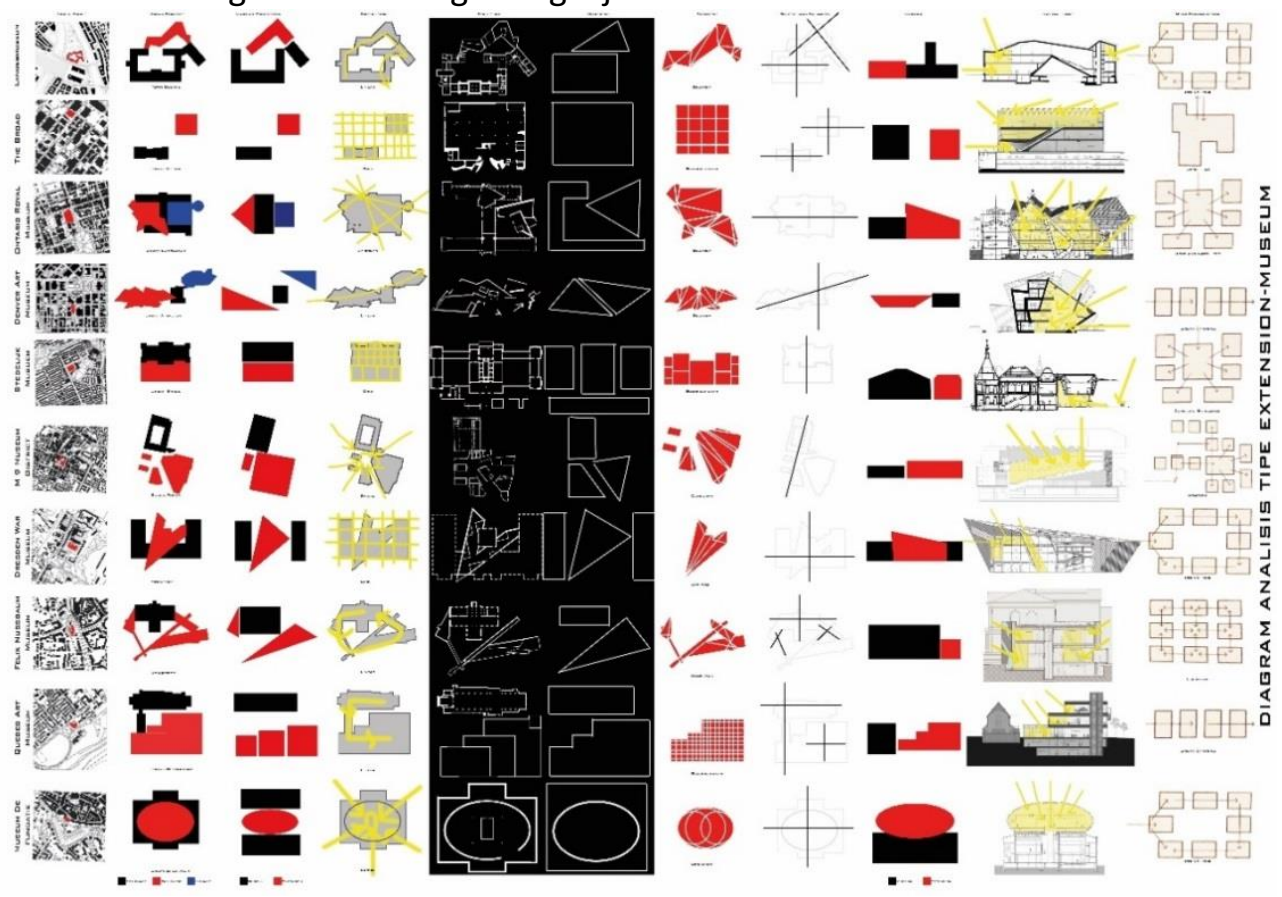

Gambar 2. Diagram Analisis Tipologi

Sumber: Penulis, 2019

\section{KESIMPULAN DAN SARAN}

Dalam penelitian mengenai ekspansi museum, yang mengacu pada metode D.K.Ching tentang titk, garis, permukaan dan volume, ditemukan terdapat pola dan karakter yang sama dilihat dari sepuluh objek museum dengan ekspansinya. Karakter dan pola tersebut adalah besaran masa eksisting dan ekspansi mempunyai besaran yang tidak berbeda jauh, bentukan massa yang menyerupai dan mengikuti axis dan sumbu yang sudah ada. Perbedaannya adalah ekspansi museum tidak memiliki sirkulasi dan organisasi ruang yang berbeda dengan bangunan eksisting.

\section{REFERENSI}

Ching, F. D.K. (2014). Architecture : Form, Space,\& Order $4^{\text {th }}$ Edition. New Jersey : Willey.

Clark, R. H. \& Michael, P. (2004). Precedents in Architecture: Analytic Diagrams, Formative Ideas, and Partis 3rd Edition. New jersey : Willey.

Tschumi, B. (1996). Architecture and Disjuction. Boston : MIT Press.

Tschumi, B. (2014). Bernard Tschumi: Tschumi Parc de La Villette. London : Artifice Book on Architecture. 